\title{
Hubungan Unsafe Action dan Unsafe Condition dengan Kecelakaan Kerja pada Pekerja Industri Mebel
}

\section{The Relationship between Unsafe Action and Unsafe Condition with Work Accidents in Furniture Industry Workers}

\author{
Adhwa Umniyyah Danur Irkas ${ }^{1}$, Azizah Musliha Fitri², Ayu Anggraeni Dyah Purbasari ${ }^{3}$, \\ Terry Y.R. Pristya ${ }^{4}$ \\ Fakultas Ilmu Kesehatan, Universitas Pembangunan Nasional Veteran Jakarta, Indonesia
}

\section{ARTICLE INFO}

\section{Article history}

Received date

07 Oct 2020

Revised date

12 Oct 2020

Accepted date

22 Oct 2020

Keywords:

Unsafe action;

Unsafe condition;

Work accidents.

\section{Kata kunci:}

Unsafe action; Unsafe condition; Kecelakaan kerja.

\author{
ABSTRACT/ ABSTRAK
}

The furniture industry was one of many industries that are necessities part of human life. The purpose of this study was to analyze the relationship between age, length of work, hours of work, OSH knowledge, unsafe action, and unsafe condition with workplace accidents in furniture industry workers in the Duren Sawit Subdistrict in 2020. The method used in this study was a quantitative analysis method with a cross-sectional study design. The sample in this study were 57 workers. The result obtained using the chi-square test was the variable age, hours of work, and unsafe condition found the value of p-value>0,05 or there was not any relationship. The variable length of work, OSH knowledge, and unsafe action obtained value of $\mathrm{p}$-value $<0,05$ or there was a relationship. The recommended action for workers and shop owners is to increase awareness in using PPE when working, always maintain cleanliness and implement OSH behavior in the workplace, always obey the rules and remind each other if there are workers who do not obey the rules, and always maintain tidiness at the place and make workplace cleaning efforts more routine.

Industri mebel adalah satu dari banyaknya bidang industri yang berperan penting bagi kehidupan manusia. Tujuan dari penelitian ini adalah untuk menganalisis hubungan antara usia, masa kerja, jam kerja, pengetahuan $\mathrm{K} 3$, unsafe action dan unsafe condition dengan kecelakaan kerja pada pekerja industri mebel di Kecamatan Duren Sawit Tahun 2020. Metode yang digunakan dalam penelitian ini adalah metode analisis kuantitatif dengan desain studi cross sectional. Sampel pada penelitian ini adalah sebanyak 57 pekerja. Hasil yang diperoleh menggunakan uji chi-square yaitu pada variabel usia, jam kerja, dan unsafe condition didapatkan nilai $p$-value $>0,05$ atau tidak ada hubungan. Pada variabel masa kerja, pengetahuan K3 dan unsafe action didapatkan nilai p-value $<0,05$ atau ada hubungan. Tindakan yang disarankan bagi pekerja dan pihak pemilik toko adalah meningkatkan kesadaran dalam menggunakan APD saat bekerja, senantiasa menjaga kebersihan dan menerapkan perilaku K3 di tempat kerja, selalu mematuhi aturan dan saling mengingatkan jika terdapat pekerja yang tidak mematuhi aturan, dan selalu menjaga kerapihan di tempat serta melakukan upaya pembersihan tempat kerja lebih rutin.

Corresponding Author:

Adhwa Umniyyah Danur Irkas

Fakultas Ilmu Kesehatan, Universitas Pembangunan Nasional Veteran Jakarta, Indonesia

Email: adhwaumniyyah@upnvj.ac.id 


\section{PENDAHULUAN}

Industri mebel adalah satu dari banyaknya bidang industri yang berperan penting bagi kehidupan manusia. Dalam pengerjaan bahan baku menjadi produk mebel siap digunakan dilalui oleh beberapa tahap seperti pemotongan, penyerutan, pengukiran, pengamplasan, dan proses finishing. Produk yang pada umumnya dihasilkan oleh industri mebel antara lain adalah pintu, kursi, jendela, meja, dan produk-produk hasil olahan kayu lainnya yang biasa dipakai di kehidupan sehari-hari. Namun, ketika proses pengolahan bahan baku dilakukan pada kayu agar dijadikan hasil mebel menimbulkan risiko pada terjadinya kecelakaan kerja, seperti jatuh, tertimpa sesuatu, teriris dan lainnya sebagai akibat adanya unsafe action (tindakan tidak selamat) atau unsafe condition (kondisi tidak selamat) (Umamah, 2016).

World Health Organization (WHO) mendefinisikan bahwa cidera yang riil adalah hasil dari kecelakaan atau kejadian yang sebelumnya tidak bisa dipersiapkan pengendalian (Wahyudi, 2018). Peraturan Menteri Ketenagakerjaan (Permenaker) Republik Indonesia Nomor: 03/MEN/98 Tentang Tata Cara Pelaporan dan Pemeriksaan Kecelakaan Bab 1 Ayat 1 berbunyi: "Kecelakaan adalah suatu kejadian yang tidak dikehendaki dan tidak diduga semula yang dapat menimbulkan korban manusia dan atau harta benda".

International Labour Organization (ILO) memperkirakan bahwa sekitar 2,78 pekerja meninggal akibat kecelakaan atau penyakit terkait kerja setiap tahun dengan lebih dari $380.000(13,7 \%)$ kematian karena kecelakaan kerja. ILO (2018) juga mengatakan bahwa kecelakaan kerja non-fatal terjadi lebih banyak dari yang fatal dengan perkiraan pekerja dengan kecelakaan non-fatal sebanyak 375 juta pekerja setiap tahun dan tentu saja terdapat konsekuensi yang serius bagi penghasilan pekerja.

Berdasarkan data di Indonesia yang didapatkan dari Badan Penyelenggara Jaminan Sosial (BPJS) Ketenagakerjaan, tercatat sepanjang tahun 2019 kasus kecelakaan kerja sebanyak 77.295 kasus, hal ini menunjukkan adanya penurunan dari tahun 2018 yaitu sebanyak 173.105 kasus dan 2017 yaitu sebanyak 123.041 kasus.

Menurut teori yang dikemukakan oleh Ramli (2010), dampak kecelakaan kerja terbagi menjadi 2, yaitu kerugian langsung maupun secara tidak langsung. Kerugian berupa materi maupun Sumber Daya Manusia (SDM) dapat mempengaruhi pelaksanaan kegiatan produksi, terutama jika meningat bahwa SDM merupakan sumber daya yang tidak dapat tergantikan (Widiatmoko, 2013).

Menurut teori domino Heinrich, sebesar 88\% kecelakaan merupakan hasil dari unsafe action dan $10 \%$ disebabkan dari unsafe condition. Lalu, berdasarkan data statistik di Indonesia, sebesar $80 \%$ kecelakaan adalah sebagai akibat dari unsafe action, 20\% oleh unsafe condition (Silalahi, 1995 dalam Primadianto, Putri \& Alifen, 2018).

Menurut Irzal (2016) sikap dan perbuatan yang tidak selamat, kurang pengetahuan dan keterampilan, cacat tubuh yang tak terlihat, letih serta lesu merupakan definisi dari unsafe action, sedangkan alat pelindung dan pakaian kerja yang tidak cocok, bahan-bahan berbahaya, ventilasi dan penyinaran yang kurang, serta alat atau mesin yang tidak selamat dan tidak efektif merupakan definisi dari unsafe condition.

Selain unsafe action dan unsafe condition, menurut ILO (1998) karakteristik individu (masa kerja, usia, pengetahuan, jenis kelamin, tingkat pendidikan, jam kerja atau shift kerja, keterampilan, kondisi fisik, perilaku, sikap) faktor manajemen (sosialisasi K3 (Keselamatan dan Kesehatan Kerja), kebijakan, Standar Operasional Prosedur (SOP), pelatihan) dan juga faktor lingkungan (ventilasi, kebisingan, pencahayaan, housekeeping, warna dan label peringatan) juga merupakan penyebab dari terjadinya kecelakaan kerja.

Kecamatan Duren Sawit, Jakarta Timur sudah dikenal sebagai salah satu wilayah industri pengrajin mebel terbesar di Jakarta. Toko dalam penelitian ini merupakan tempat produksi sekaligus tempat penjualan. Dalam proses produksi, para pekerja menggunakan alat pengolahan kayu baik dengan mesin atau manual seperti gergaji, gerinda, plener dan spindle untuk pemotongan, alat pengamplasan otomatis atau manual, alat penyerutan kayu, dan peralatan lainnya yang umum digunakan di industri mebel. Dari studi pendahuluan yang dilakukan melalui wawancara pada bulan Maret 2020, tercatat bahwa dari seluruh populasi, beberapa responden menyatakan sudah pernah mengalami kecelakaan kerja dan beberapa menyatakan tidak pernah.

Adapun beberapa faktor/permasalahan penyebab kecelakaan kerja adalah dikarenakan para pekerja kurang menerapkan $\mathrm{K} 3$ seperti tidak menggunakan APD, tumpukan barang juga alat kerja yang diletakkan sembarangan, serta mindset beberapa pekerja yang merasa bahwa kecelakaan kerja yang mereka alami merupakan salah satu hal yang lumrah. Sudah banyak dampak dari kejadian kecelakaan kerja yang dialami, baik dari 
kerugian secara materi, waktu kerja, ataupun bagi individu.

\section{METODE}

Penelitian ini adalah penelitian analitik kuantitatif dengan desain studi cross sectional. Penelitian dilakukan pada kurun waktu 3 bulan, dimulai sejak bulan April sampai bulan Juni 2020 di industri mebel yang bertempat di Kecamatan Duren Sawit, Jakarta Timur. Sampel pada penelitian ini yaitu sebanyak 57 responden dengan metode purposive sampling. Instrumen penelitian yang digunakan yaitu kuesioner untuk variabel usia, masa kerja, jam kerja, serta pengetahuan K3 dan check list untuk variabel kecelakaan kerja, unsafe action, serta unsafe condition. Teknik analisis data yang digunakan pada penelitian ini adalah analisis univariat dan bivariat. Analisis menggunakan uji chi-square digunakan dengan batas kemaknaan $\alpha$ 0,05 dan estimasi Confidential Interval (CI) $95 \%$ (Sumairawan, 2019).

Penelitian ini telah mendapatkan persetujuan etik (Ethical Approval) dengan Nomor: B/2546/VI/2020/KEPK oleh Komisi Etik Penelitian Kesehatan Univesitas Pembangunan Nasional Veteran Jakarta.

HASIL

Tabel 1. Distribusi Responden Berdasarkan Kejadian Kecelakaan Kerja pada Pekerja Industri Mebel

\begin{tabular}{lll}
\hline $\begin{array}{l}\text { Kejadian } \\
\text { Kecelakaan Kerja }\end{array}$ & n & \% \\
\hline Tidak & 14 & 24,6 \\
Ya & 43 & 75,4 \\
\hline
\end{tabular}

Pada tabel 1 didapatkan dari total 57 responden, dalam jangka waktu 1 tahun terakhir sejumlah 43 pekerja $(75,4 \%)$ pernah mengalami kecelakaan kerja dan sebanyak 14 pekerja $(24,6 \%)$ tidak pernah mengalami kecelakaan kerja. Hal tersebut menunjukkan lebih banyak responden yang pernah mengalami kecelakaan kerja dibandingkan dengan yang tidak pernah mengalami kecelakaan kerja.
Tabel 2. Distribusi Responden Berdasarkan Jenis Kecelakaan Kerja yang Pernah Dialami pada Pekerja Industri Mebel

\begin{tabular}{|c|c|c|c|c|c|c|}
\hline \multirow{3}{*}{$\begin{array}{c}\text { Jenis } \\
\text { Kecelakaan } \\
\text { Kerja }\end{array}$} & \multicolumn{4}{|c|}{$\begin{array}{c}\text { Responden yang } \\
\text { Mengalami }\end{array}$} & \multirow{2}{*}{\multicolumn{2}{|c|}{ Total }} \\
\hline & \multicolumn{2}{|c|}{ Tidak } & \multicolumn{2}{|c|}{ Ya } & & \\
\hline & $\mathbf{n}$ & $\%$ & $\mathbf{n}$ & $\%$ & $\mathbf{n}$ & $\%$ \\
\hline Terjatuh & 47 & 82,5 & 10 & 17,5 & 57 & 100 \\
\hline $\begin{array}{l}\text { Tertimpa } \\
\text { benda jatuh }\end{array}$ & 32 & 56,1 & 25 & 43,9 & 57 & 100 \\
\hline Tertusuk & 42 & 73,7 & 15 & 26,3 & 57 & 100 \\
\hline Tersayat & 32 & 56,1 & 25 & 43,9 & 57 & 100 \\
\hline Tertumbuk & 26 & 45,6 & 31 & 54,4 & 57 & 100 \\
\hline Terjepit & 27 & 47,4 & 30 & 52,6 & 57 & 100 \\
\hline Terpotong & 57 & 100 & 0 & 0 & 57 & 100 \\
\hline $\begin{array}{l}\text { Tersengat } \\
\text { arus listrik }\end{array}$ & 35 & 61,4 & 22 & 38,6 & 57 & 100 \\
\hline
\end{tabular}

Pada tabel 2 distribusi data kecelakaan kerja tertinggi yang pernah dialami responden adalah tertumbuk yaitu sejumlah 31 orang yang mengalami $(54,4 \%)$ dan jenis kecelakaan terendah yang pernah dialami adalah terpotong yaitu tidak ada responden yang mengalami $(0 \%)$. Tertumbuk menempati posisi pertama jenis kecelakaan kerja yang dialami responden, tapi tidak sedikit pekerja yang tidak pernah mengalami jenis kecelakaan kerja tersebut karena beberapa faktor seperti berhati-hati saat bekerja, periode kerja yang masih sebentar, dan beberapa faktor lainnya.

Tabel 3. Distribusi Frekuensi Hasil Analisis Univariat pada Pekerja Industri Mebel

\begin{tabular}{lll}
\hline Variabel & f & \% \\
\hline Usia & & \\
$<38$ tahun & 23 & 40,4 \\
$\geq 38$ tahun & 34 & 59,6 \\
Masa Kerja & & \\
$\quad<3$ tahun & 24 & 42,1 \\
$\quad \geq 3$ tahun & 33 & 57,9 \\
Jam Kerja & & \\
$\quad \leq 8$ jam & 18 & 31,6 \\
$\quad>8$ jam & 39 & 68,4 \\
Pengetahuan K3 & & \\
$\quad$ Baik & 23 & 40,4 \\
$\quad$ Kurang & 34 & 59,6 \\
Unsafe Action & & \\
$\quad$ Rendah & 24 & 42,1 \\
$\quad$ Tinggi & 33 & 57,9 \\
Unsafe Condition & & \\
$\quad$ Rendah & 23 & 40,4 \\
Tinggi & 34 & 59,6 \\
\hline
\end{tabular}

Pada tabel 3 distribusi data bahwa pekerja industri mebel di Kecamatan Duren Sawit memiliki hasil distribusi frekuensi pada variabel usia yaitu sebanyak 23 responden $(40,4 \%)$ 
berusia $<38$ tahun dan 34 responden $(59,6 \%)$ memiliki usia $\geq 38$ tahun, hal tersebut berarti responden pada kategori usia $\geq 38$ tahun lebih banyak dan lebih berisiko. Pada variabel masa kerja, terdapat hasil distribusi frekuensi bahwa responden dengan periode kerja $\geq 3$ tahun lebih banyak distribusinya serta lebih berisiko yaitu sebanyak 33 responden (57,9\%) dibandingkan dengan responden dengan periode kerja $<3$ tahun yaitu sebanyak 24 responden $(42,1 \%)$. Pada variabel jam kerja, terdapat hasil distribusi frekuensi bahwa mayoritas responden bekerja selama $>8$ jam dengan jumlah sebanyak 39 responden $(68,4 \%)$ lebih berisiko dibandingkan dengan responden yang bekerja selama $\leq 8$ jam yaitu sebanyak 18 responden $(31,6 \%)$. Pada variabel pengetahuan $\mathrm{K} 3$, terdapat hasil distribusi frekuensi bahwa responden dengan tingkat pengetahuan kurang sejumlah 34 responden $(59,6 \%)$ atau lebih banyak dan lebih berisiko dibandingkan responden dengan tingkat pengetahuan baik yaitu sebanyak 23 responden $(40,4 \%)$. Pada variabel unsafe action, terdapat hasil distribusi frekuensi bahwa sebanyak 33 responden $(57,9 \%)$ memiliki tingkat unsafe action tinggi atau lebih banyak dan lebih berisiko dibandingkan dengan responden yang memiliki tingkat unsafe action rendah yaitu sebesar 24 responden (42,1\%). Pada variabel unsafe condition, hasil distribusi frekuensi menunjukkan lebih banyak pekerja yang memiliki tingkat unsafe condition tinggi dan lebih berisiko yaitu sebanyak 34 responden $(59,6 \%)$ dibandingkan pekerja dengan tingkat unsafe condition rendah yaitu sejumlah 23 responden $(40,4 \%)$.

Tabel 4. Hasil Analisis Bivariat Hubungan Unsafe Action dan Unsafe Condition dengan Kecelakaan Kerja pada Pekerja Industri Mebel

\begin{tabular}{|c|c|c|c|c|c|c|c|c|}
\hline \multirow{3}{*}{ Variabel } & \multicolumn{6}{|c|}{ Kecelakaan Kerja } & \multirow{3}{*}{$p$-value } & \multirow{3}{*}{ OR 95\% CI } \\
\hline & \multicolumn{2}{|c|}{ Tidak } & \multicolumn{2}{|c|}{ Ya } & \multicolumn{2}{|c|}{ Total } & & \\
\hline & $\mathbf{n}$ & $\%$ & n & $\%$ & $\mathbf{n}$ & $\%$ & & \\
\hline \multicolumn{9}{|l|}{ Usia } \\
\hline$<38$ tahun & 7 & 30,4 & 16 & 69,6 & 23 & 100 & 0,594 & $1,688(0,500-5,696)$ \\
\hline$\geq 38$ tahun & 7 & 20,6 & 27 & 79,4 & 34 & 100 & & \\
\hline \multicolumn{9}{|l|}{ Masa Kerja } \\
\hline$<3$ tahun & 11 & 45,8 & 13 & 54,2 & 24 & 100 & 0,004 & $8,462(2,019-35,462)$ \\
\hline$\geq 3$ tahun & 3 & 9,1 & 30 & 90,9 & 33 & 100 & & \\
\hline \multicolumn{9}{|l|}{ Jam Kerja } \\
\hline$\leq 8 \mathrm{jam}$ & 5 & 27,8 & 13 & 72,2 & 18 & 100 & 0,747 & $1,282(0,359-4,576)$ \\
\hline$>8 \mathrm{jam}$ & 9 & 23,1 & 30 & 76,9 & 39 & 100 & & \\
\hline \multicolumn{9}{|c|}{ Pengetahuan K3 } \\
\hline Baik & 10 & 43,5 & 13 & 56,5 & 23 & 100 & 0,016 & $5,769(1,526-21,807)$ \\
\hline Kurang & 4 & 11,8 & 30 & 88,2 & 34 & 100 & & \\
\hline \multicolumn{9}{|l|}{ Unsafe Action } \\
\hline Rendah & 10 & 41,7 & 14 & 58,3 & 24 & 100 & 0,025 & $5,179(1,379-19,451)$ \\
\hline Tinggi & 4 & 12,1 & 29 & 87,9 & 33 & 100 & & \\
\hline \multicolumn{9}{|c|}{ Unsafe Condition } \\
\hline Rendah & 9 & 39,1 & 14 & 60,9 & 23 & 100 & 0,074 & $3,729(1,052-13,220)$ \\
\hline Tinggi & 5 & 14,7 & 29 & 85,3 & 34 & 100 & & \\
\hline
\end{tabular}

\section{PEMBAHASAN}

\section{Kejadian Kecelakaan Kerja}

Berlandaskan pada hasil studi yang telah dilaksanakan, bahwa $75,4 \%$ pekerja pernah mengalami kecelakaan kerja, jumlah tersebut lebih banyak dibandingkan dengan responden yang tidak pernah mengalami kecelakaan kerja. Adapun tipe kecelakaan kerja yang dialami adalah terjatuh, tertimpa benda jatuh, tertusuk, tersayat, tertumbuk, terjepit, dan tersengat arus listrik. Dari semua insiden kecelakaan yang pernah ada, tidak terdapat kejadian kecelakaan kerja yang fatal hingga meninggal dunia. Meskipun mayoritas kasus kecelakaan kerja masih tergolong ringan dan tidak ada korban jiwa, tetap diperlukan pemantauan dan kesadaran bagi pemilik toko dan pekerja agar tidak terjadi kejadian fatal di masa yang akan datang.

\section{Hubungan Usia dengan Kecelakaan Kerja}

Tidak ada korelasi antara usia dengan kecelakaan kerja, dinyatakan dengan nilai $p$ value $=0,594$ yang berarti $>0,05$ sehingga Ho diterima.

Meskipun menurut Depkes (1990) dalam Winarto, Denny \& Kurniawan (2016) pekerja 
dengan usia muda cenderung sering melakukan kesalahan ketika bekerja, kurang disiplin, ceroboh, tergesa-gesa, lebih mengikuti kata hati, dan kurang peduli. Namun ketika seseorang berusia semakin tua, fungsi tubuh juga akan ikut menurun setelah seseorang mencapai kondisi fisik optimalnya yaitu ketika pada usia 30 tahun, yang setiap tahunnya akan menurun sebesar $1 \%$ seperti pada pendengaran, penglihatan, ketanggapan dalam membedakan sesuatu, menghasilkan keputusan, serta kemampuan jangka pendek (Anwar \& Sugiharto, 2018).

Hal tersebut membuktikan bahwa kecelakaan kerja dapat dialami seseorang berapapun usianya. Faktor atau permasalahan lain yang memungkinkan pekerja berusia tua lebih sering mengalami kecelakaan kerja adalah pekerja dengan usia tua terkadang merasa sudah terbiasa dan tidak masalah dengan adanya kecelakaan kerja sehingga kurang memerhatikan keselamatan diri untuk terhindar dari kecelakaan kerja.

\section{Hubungan Masa Kerja dengan Kecelakaan Kerja}

Mayoritas pekerja yang memiliki masa kerja $\geq 3$ tahun pernah mengalami kecelakaan kerja lebih banyak dari pekerja yang memiliki masa kerja $<3$ tahun. Hasil uji chi-square pada nilai $p$-value $=0,004 \quad(<0,05)$ sehingga terdapat hubungan antara masa kerja dengan kecelakan kerja.

Lama kerja seseorang dapat memberikan pengaruh positif ataupun negatif, contoh positifnya adalah bertambahnya pengalaman pada pekerja, negatifnya adalah timbulnya kebiasaan monoton pada pekerja (Sulhinayatillah, 2017). Masa kerja berpengaruh terhadap kejadian kecelakaan kerja, akan tetapi bukan berarti pekerja dengan periode kerja masih sebentar selalu berisiko lebih sering mengalami kecelakaan kerja. Terkadang pekerja yang baru bekerja di suatu tempat cenderung lebih waspada serta menaati regulasi yang berlaku, pekerja baru juga cenderung tidak berani jika melanggar regulasi di tempat kerja, mereka juga belum banyak melakukan berbagai jenis kegiatan di tempat kerja seperti pekerja lainnya yang sudah lama bekerja. Selain itu, pengetahuan atau tindakan selamat yang dimiliki pekerja baru juga berkemungkinan mempengaruhi kejadian kecelakaan kerja responden meskipun mereka masih tergolong baru bekerja.

\section{Hubungan Jam Kerja dengan Kecelakaan Kerja}

Sesuai dengan hasil penelitian bahwa banyaknya responden yang pernah mengalami kecelakaan kerja dengan jam kerja $>8$ jam melebihi banyaknya responden yang pernah mengalami kecelakaan kerja dengan jam kerja $\leq 8$ jam. Hasil uji chi-square menunjukkan nilai $p$ value $=0,747$ yang berarti $>0,05$ sehingga Ho diterima atau tidak terdapat hubungan antara jam kerja dengan kecelakan kerja.

Didasari oleh terbatasnya sumber daya dan fasilitas yang dipunyai, konsekuensi bagi pekerja informal ialah wajib kerja dengan ekstra seperti $>8$ jam sehari demi memenuhi kebutuhan pasar (Zurriya, Thamrin \& Ikhtiar, 2019). Walaupun demikian, ketika seseorang memiliki jam kerja $>8$ jam per hari atau memiliki jam kerja cukup lama, tetapi jika diimbangi dengan memiliki waktu istirahat yang cukup selama bekerja dan selalu bertindak selamat saat bekerja maka tidak menutup kemungkinan dapat meminimalisir terjadinya kecelakaan kerja.

\section{Hubungan Pengetahuan K3 dengan Kecelakaan Kerja}

Mayoritas responden yang pernah mengalami kecelakaan kerja memiliki tingkat pengetahuan kurang dibandingkan dengan tingkat pengetahuan baik. Didapatkan hasil melalui uji chi-square bahwa terdapat hubungan antara pengetahuan K3 terhadap kecelakaan kerja, hal tersebut dibuktikan dengan nilai $p$-value $=0,016$ $(<0,05)$.

Pada dasarnya, ketika seseorang berpengetahuan kurang, hal tersebut akan menyebabkan pengabaian pada bahaya disekitarnya dan tidak melakukan pekerjaan sesuai ketentuan yang ada serta tidak menyadari berbagai risiko yang akan diterima (Siregar, 2014). Begitu pula sebaliknya, ketika seseorang berpengetahuan baik, ia akan senantiasa bertindak yang baik pula serta dapat terhindar dari kecelakan kerja (Syaputra, 2017), pekerja jadi lebih menyadari bagaimana cara agar selalu berada dalam keadaan selamat ketika bekerja dan menyadari apa saja risiko yang terjadi ketika bekerja tidak sesuai dengan prosedur yang seharusnya.

\section{Hubungan Unsafe Action dengan Kecelakaan Kerja}

Pada hasil studi, didapatkan data responden yang pernah mengalami kecelakaan 
kerja pada kategori unsafe action tinggi lebih banyak dibandingkan dengan responden yang pernah mengalami kecelakaan kerja dengan pada kategori unsafe action rendah. Hasil uji chisquare menunjukkan $p$-value $=0,025(<0,05)$ yang berarti terdapat hubungan antara unsafe action terhadap kecelakan kerja.

Unsafe action merupakan penyimpangan tindakan terhadap aturan dan membahayakan bagi diri sendiri, orang lain, ataupun peralatannya (Hasrinal, Darma \& Diana, 2018). Perilaku tidak selamat merupakan kategori perilaku yang menjurus terhadap kecelakaan layaknya melaksanakan pekerjaan tidak memedulikan keselamatan, menjalankan pekerjaan tanpa adanya izin terlebih dahulu, pengabaian terhadap peralatan keselamatan, melakukan tindakan pekerjaan dengan kecepatan yang membahayakan, mengoperasikan peralatan tidak sesuai standar, bertindak kasar, minim pengetahuan, emosi yang cukup tidak stabil atau cacat tubuh (Agivina, 2015 dalam Rusdjijati, Sugiarto \& Raliby, 2017). Teori yang dikatakan oleh Heinrich juga menunjukkan bahwa $88 \%$ kecelakaan kerja terjadi akibat perilaku tidak selamat dari pekerja itu sendiri. Unsafe action erat hubungannya dengan kejadian kecelakaan kerja, karena tindakan atau perilaku pekerja selama bekerja dapat mempengaruhi keselamatan pekerja. Ketika seorang pekerja tidak melakukan proteksi diri terhadap bahaya di sekitar tempat kerja, hal tersebut akan meningkatkan risiko terjadinya kecelakaan kerja dan begitu pula sebaliknya (Silalahi, 1995 dalam Primadianto, Putri \& Alifen, 2018).

Kesadaran dari pekerja mengenai pemakaian APD, pentingnya untuk selalu berhati-hati ketika bekerja, selalu menjaga kebersihan dan kerapihan, tidak merokok atau bercanda ketika bekerja, selalu memeriksa keadaan alat dan penempatan alat kerja yang sesuai ketika sedang tidak digunakan dapat membantu meminimalisasi peluang insiden kecelakaan kerja. Sebaliknya, ketika seorang pekerja dalam keadaan sakit saat bekerja, tidak memeriksa dan tidak menyimpan peralatan, terburu-buru saat bekerja, membuang sampah sembarangan, mengobrol dan merokok saat bekerja, serta tidak menggunakan APD seperti masker, sarung tangan, serta alas kaki, maka hal tersebut akan mengurangi konsentrasi serta performansi pekerja dan menimbulkan kecelakaan kerja. Selain itu, tindakan pekerja yang tidak selamat juga dapat meningkatkan kemungkinan terjadinya kecelakaan kerja pada pekerja lainnya atau bahkan mencelakai tamu atau konsumen yang sedang berkunjung, sehingga dapat berpengaruh juga terhadap citra perusahaan atau tingkat kepercayaan konsumen.

\section{Hubungan Unsafe Condition dengan Kecelakaan Kerja}

Berlandaskan tabel 4, didapatkan data bahwa mayoritas responden yang mengalami kecelakaan kerja termasuk dalam unsafe condition tinggi dibandingkan dengan responden yang mengalami kecelakaan kerja dengan kategori unsafe condition rendah. Hasil uji chisquare pada nilai $p$-value $=0,074$ yang berarti $>0,05$ sehingga Ho diterima atau tidak terdapat hubungan antara unsafe condition dengan kecelakan kerja.

Unsafe condition dalam penelitian ini disebabkan oleh beberapa hal seperti tumpukan barang di tempat kerja, alat-alat kerja yang berserakan, tidak tersedianya APD, lantai yang tidak mudah dibersihkan dan licin, tempat kerja sempit, tumpukan sampah dan gulungan kabel yang berbahaya/mengganggu, serta kurangnya ventilasi udara dan sumber pencahayaan. Lingkungan kerja yang tidak memenuhi persyaratan akan memiliki kemungkinan timbulnya insiden kecelakaan kerja (Kairupan, Doda \& Kairupan, 2019). Namun, walaupun kondisi tempat kerja termasuk ke dalam kategori unsafe condition tinggi, hal tersebut tidak sepenuhnya berpengaruh apabila pekerja dapat menerapkan upaya proteksi diri ketika bekerja. Seperti teori yang sudah dikemukakan oleh Heinrich bahwa unsafe condition berpengaruh $10 \%$ terhadap kecelakaan, sedangkan unsafe action jauh lebih besar yaitu 88\% (Silalahi, 1995 dalam Primadianto, Putri \& Alifen, 2018). Sebut saja ketika perusahaan tidak menyediakan APD kepada pekerja, hal tersebut tidak akan terlalu berpengaruh jika pekerja senantiasa memakai APD yang mereka punya karna tingginya kesadaran untuk menerapkan tindakan selamat. Atau, walaupun lantai tempat kerja tidak mudah dibersihkan, namun jika pekerja senantiasa menjaga kebersihan dan keselamatan lingkungan maka hal tersebut juga cukup berpengaruh terhadap upaya pencegahan kecelakaan kerja.

\section{SIMPULAN}

Usia, jam kerja, dan unsafe condition dengan kecelakaan kerja tidak memiliki hubungan, sedangkan masa kerja, pengetahuan $\mathrm{K} 3$ dan unsafe action dengan kecelakaan kerja memiliki hubungan. 
Perlu peningkatan kesadaran pekerja dalam menggunakan APD saat bekerja, senantiasa menjaga kebersihan dan menerapkan perilaku K3 di tempat kerja, selalu mematuhi aturan dan saling mengingatkan jika terdapat pekerja yang tidak mematuhi aturan, dan selalu menjaga kerapihan di tempat serta melakukan upaya pembersihan tempat kerja lebih rutin.

\section{DAFTAR PUSTAKA}

Anwar, M., \& Sugiharto. (2018). Penyebab Kecelakaan Kerja PT. Pura Barutama Unit Offset. Jurnal Higeia, 2(3), 386-395. doi: https://doi.org/10.15294/higeia/v2i3/21514

BPJS Ketenagakerjaan. (2019). Angka Kecelakaan Kerja Cenderung Meningkat, BPJS Ketenagakerjaan Bayar Santunan Rpl,2 Triliun. https://www.bpjsketenagakerjaan.go.id/ber ita/23322/Angka-Kecelakaan-Kerja-

Cenderung-Meningkat,-BPJS-

Ketenagakerjaan-Bayar-Santunan-Rp1,2Triliun.

Hasrinal, Darma, I. Y., \& Diana, J. R. (2018). Hubungan Unsafe Act Dan Unsafe Condition Dengan Kejadian Kecelakaan Kerja Pada Pekerja Bengkel Mobil. Jurnal Kesehatan Medika Saintika, 10(2), 101107.https://jurnal.syedzasaintika.ac.id.

ILO. (1998). Encyclopedia of Occupational Health and Safety. Edited by J. M. Stellman. Geneva.

ILO. (2018). Meningkatkan Keselamatan dan Kesehatan Pekerja Muda. Kantor Perburuhan Internasional, CH-1211 Geneva 22, Switzerland.

Irzal. (2016). Dasar-dasar Kesehatan dan Keselamatan Kerja. Jakarta: Kencana.

Kairupan, F. A., Doda, D. V., \& Kairupan, B. H. R. (2019). Hubungan antara Unsafe Action dan Unsafe Condition dengan Kecelakaan Kerja pada Pengendara Ojek Online dan Ojek Pangkalan di Kota Manado. Jurnal KESMAS, 8(6), 89-98. https://ejournal.unsrat.ac.id/index.php/kes mas/article/view/25419

Permenaker. (1998). Peraturan Menteri Ketenagakerjaan Republik Indonesia Nomor: 03/MEN/98 Tentang Tatacara Pelaporan dan Pemeriksaan Kecelakaan. https://jdih.kemnaker.go.id/data_wirata/19 98-2-4.pdf

Primadianto, D., Putri, S. K., \& Alifen, R. S. (2018). Pengaruh Tindakan Tidak Aman (Unsafe Act) Dan Kondisi Tidak Aman (Unsafe Condition) Terhadap Kecelakaan Kerja Konstruksi. Jurnal Teknik Sipil, 7(1), 77-84. http://publication.petra.ac.id/index.php/tek nik-sipil/article/view/7036

Ramli, S. (2010). Sistem Manajemen Keselamatan dan Kesehatan Kerja OHSAS 18001. Jakarta: Dian Rakyat.

Rusdjijati, R., Sugiarto, S. S. A., \& Raliby, O. (2017). Unsafety Behaviour Pekerja Di Industri Kayu Lapis Yang Berpotensi Menyebabkan Kecelakaan Kerja. Jurnal Seminar Nasional IENACO (Industrial Engineering National Conference), 195-201. https://publikasiilmiah.ums.ac.id/xmlui/ha ndle/11617/8678

Siregar, D. I. S. (2014). Faktor-Faktor Yang Berhubungan Dengan Kecelakaan Ringan Di PT Aqua Golden Mississippi Bekasi Tahun 2014. [Skripsi]. Jakarta: Universitas Islam Negeri Syarif Hidayatullah. http://repository.uinjkt.ac.id/dspace/handle $/ 123456789 / 25512$

Sulhinayatillah. (2017). Faktor-Faktor Yang Berhubungan Dengan Kejadian Kecelakaan Kerja Pada Karyawan Bagian Produksi Di PT. PP London Sumatera Indonesia Tbk. Palangisang Crumb Rubber Factory Bulukumba Tahun 2017. [Skripsi]. Makassar: Universitas Islam Negeri Alauddin Makassar. http://repositori.uinalauddin.ac.id/id/eprint/8104

Sumairawan, B. R. (2019). Hubungan Unsafe Act Dan Unsafe Condition Dengan Kecelakaan Kerja Pada Pekerja Di Bagian Produksi CV. Gerimis Garment Jakarta Tahun 2019. [Skripsi]. Jakarta: Universitas Pembangunan Nasional Veteran Jakarta. http://repository.upnvj.ac.id/

Syaputra, E. M. (2017). Hubungan Pengetahuan dan Motivasi K3 dengan Kecelakaan Kerja Karyawan Produksi PT Borneo Melintang Buana Eksport. Afiasi: Jurnal Kesehatan Masyarakat, 2(3), 97-103. https://afiasi.unwir.ac.id/index.php/afiasi/a rticle/view/54

Umamah, F. N. (2016). Analisis Unsafe Action Dan Unsafe Condition Dengan Kecelakaan Kerja Pada Pekerja Di Jatindo Ukir Jepara Tahun 2016. [Skripsi]. Semarang: Universitas Dian Nuswantoro. 
Wahyudi, A. (2018). Keselamatan dan Kesehatan Kerja (K3): Investigasi Kecelakaan Kerja. MODUL E Learning Asosiasi Tenaga Teknik Indonesia (ASTTI), LP2K TTI Seri K3. http://astti.or.id/sites/default/files/Seri\%20 K3\%20-\%20BAB\%205\%20\%20$\% 20 \% 20$ Kecelakaan\%20Kerja.pdf

Widiatmoko, M. N. (2013). Faktor-Faktor Yang Berhubungan Dengan Kejadian Kecelakaan Kerja Pada Pekerja Pengangkut Kayu Di Penggergajian Kayu Jepara 2013. [Skripsi]. Semarang: Universitas Dian Nuswantoro. http://eprints.dinus.ac.id/7857/1/jurnal_127 51.pdf

Winarto, S., Denny, H. M., \& Kurniawan, B. (2016). Studi Kasus Kecelakaan Kerja Pada Pekerja Pengeboran Migas Seismic Survey PT. X Di Papua Barat. Jurnal Promosi Kesehatan Indonesia, 11(1), 5165.https://ejournal.undip.ac.id/index.php/jp ki/article/view/18985

Zurriya, J., Thamrin, Y., \& Ikhtiar, M. (2019). 'Faktor Yang Berhubungan Dengan Kecelakaan Kerja Pada Bengkel Las Di Bengkel Las Di Kota Makassar 2018. Jurnal Ilmiah Kesehatan Diagnosis, 14(1), 48-52. doi: 10.35892/jikd.v14i1.95. 